\title{
Comparison of Synergistic Effect of Nisin and Monolaurin on the Inactivation of Three Heat Resistant Spores Studied by Design of Experiments in Milk
}

\author{
Souhir Kmiha $\left(\mathbb{D}\right.$, Chedia Aouadhi $\left(\mathbb{D}\right.$, Khouloud Aziza $\left(\mathbb{D}\right.$, Awatef Bejaoui $\mathbb{D}^{\mathrm{D}}$, \\ and Abderrazak Maaroufi \\ Laboratory of Epidemiology and Veterinary Microbiology. Group of Bacteriology and Biotechnology, \\ Pasteur Institute of Tunisia (IPT), Université de Tunis El Manar (UTM), BP 7413 Place Pasteur Belvédère, \\ Tunis 1002, Tunisia \\ Correspondence should be addressed to Chedia Aouadhi; chediaaouadhi@yahoo.fr
}

Received 23 March 2021; Accepted 22 December 2021; Published 31 December 2021

Academic Editor: Jorge Barros Vel zquez

Copyright $\odot 2021$ Souhir Kmiha et al. This is an open access article distributed under the Creative Commons Attribution License, which permits unrestricted use, distribution, and reproduction in any medium, provided the original work is properly cited.

Spore forming bacteria are special problems for the dairy industry. Heat treatments are insufficient to kill the spores. This is a continuously increasing problem for the industry, but we should be able to control it. In this context, we investigated the combined effect of nisin, monolaurin, and $\mathrm{pH}$ values on three heat resistant spores in UHT milk and distilled water and to select an optimal combination for the maximum spore inactivation. The inhibitory effect of nisin (between 50 and $200 \mathrm{IU} / \mathrm{ml}$ ), monolaurin (ranging from 150 to $300 \mu \mathrm{g} / \mathrm{ml}$ ), and $\mathrm{pH}$ (between 5 and 8) was investigated using a central composite plan. Results were analyzed using the response surface methodology (RSM). The obtained data showed that the inactivation of Bacillus spores by the combined effect of nisin-monolaurin varies with spore species, acidity, and nature of the medium in which the bacterial spores are suspended. In fact, Terribacillus aidingensis spores were more resistant, to this treatment, than Paenibacillus sp. and Bacillus sporothermodurans ones. The optimum process parameters for a maximum reduction of bacterial spores $(\sim 3 \log )$ were obtained at a concentration of nisin $>150 \mathrm{IU} / \mathrm{ml}$ and of monolaurin $>200 \mu \mathrm{g} / \mathrm{ml}$. The current study highlighted the presence of a synergistic effect between nisin and monolaurin against heat bacterial spores. So, such treatment could be applied by the dairy industry to decontaminate UHT milk and other dairy products from bacterial spores.

\section{Introduction}

The presence of highly heat-resistant spores of Bacillus in UHT milk has emerged as a major problem in the dairy industry as it affects the commercial sterility required for these products [1]. In addition, spore-forming bacteria become the main obstacle limiting the further extension of milk's shelf life [2]. To prevent the growth of Bacillus species, there are different kinds of heat treatments, which are used such as pasteurization and ultrahigh-temperature processing (UHT). Despite these thermal treatments ensuring the commercial sterility of the finished product, many problems regarding the sterility of UHT milk appeared [3]. The poor quality of the finished product is caused by the presence of highly heat resistant spores produced by Bacillus species. Among these, spores are those of Bacillus sporothermodurans which are described for the first time by Petterson et al. [4].

The use of antibacterial agents has gained great attention with interesting results in the destruction of vegetative cells and inactivation of bacterial spores in various food systems [5]. Nisin, monolaurin, and lactoperoxidase are examples of natural preservatives currently used in the food industry. Nisin is an antimicrobial peptide known to inhibit the growth of a number of Gram-positive bacteria including outgrowth of spores of Bacillus and Clostridium. Also, it has been shown to be effective in the microbial control of a number of pasteurized dairy products [6] and milk [5]. 
Monoglycerides are used in the food industry as favoring and emulsifying agents. Monolaurin is the most compound that has received attention because of its antimicrobial properties $[7,8]$. There are several treatments that are based on the combination of antimicrobial agents, but the appearance of species that resist this type of treatment leads us to look for other types of combinations. For that, several combinations were studied. Nisin, for example, has been used in combination with lactoperoxidase system [9], monolaurin [10], high pressure, and heat treatment [11]. Many authors showed the synergistic inhibitory effect of nisin and monolaurin, used in association, against Escherichia coli, Bacillus subtilis, and Staphylococcus aureus [12]. In a previous study, Mansour et al. [13] investigated the inhibitory synergistic effects of nisinmonolaurin used in association with $\mathrm{pH}$ on Bacillus licheniformis spores in milk. In another work, Mansour and Millière [10] studied the combined effect of these antimicrobial agents on spore reduction of three Bacillus species (Bacillus cereus, Bacillus subtilis, and Bacillus coagulans) in milk. Although the mechanisms of action of nisin and monolaurin are different, the fact that the cytoplasmic membrane is their primary action site could explain their inhibitory synergistic effect [14]. The combined effect of nisin-potassium sorbate against Bacillus sporothermodurans spores has been studied [15], but the effect of antimicrobials agents on the inactivation of B. sporothermodurans, Terribacillus aidingensis, and Paenibacillus sp. spores has not previously been investigated. The aim of our study was to evaluate the inhibitory activity of nisin-monolaurin-pH on the inactivation of Bacillus sporothermodurans, Paenibacillus sp., and Terribacillus aidingensis spores in distilled water and milk. For this purpose, response surface methodology (RSM) was used to describe the spore inactivation by combining nisin-monolaurin and $\mathrm{pH}$.

\section{Material and Methods}

2.1. Bacterial Strains. In this study, three Bacillus species were used for evaluating the effect of antimicrobials agents on bacterial spores. Bacillus sporothermodurans strain was isolated from raw milk, while Paenibacillus sp. and Terribacillus aidingensis strains were isolated from UHT milk produced in Tunisia for the first time as previously described by Kmiha et al. [16].

Paenibacillus sp., B. sporothermodurans, and T. aidingensis were grown on brain-heart-infusion agar supplemented with $1 \mathrm{mg} / \mathrm{L}$ vitamin $\mathrm{B}_{12}$ (Sigma Aldrich) (BHI-vitB $\left.{ }_{12}\right)$ at $37^{\circ} \mathrm{C}$.

2.2. Spore Suspensions. The spores were prepared as described by Aouadhi et al. [11]. The strains are cultured first in $\mathrm{BHI}$ agar-vitB $\mathrm{B}_{12}$ broth at $37^{\circ} \mathrm{C}$ for 24 hours, from a single colony obtained on a solid medium. This preculture is diluted $1 / 10$ in the sporulation broth described by Herman and others [17] $\left(25 \mathrm{~g} / \mathrm{L}\right.$ nutrient broth, $1 \mathrm{mg} / \mathrm{L}$ vitamin $\mathrm{B}_{12}$ (Sigma), $8 \mathrm{mg} / \mathrm{L}$ of $\mathrm{MnSO}_{4} \mathrm{H}_{2} \mathrm{O}$, and $1 \mathrm{~g} / \mathrm{L}$ of $\mathrm{CaCl}_{2} \mathrm{H}_{2} \mathrm{O}$ ) and incubated at $37^{\circ} \mathrm{C}$ for 7 days. After that, cultures were centrifuged at $8000 \mathrm{rpm}$ for $10 \mathrm{~min}$. The obtained pellet is suspended and washed vigorously three times with sterile distilled water. After the last washing, the bacterial pellet is suspended in $5 \mathrm{~mL}$ of sterile distilled water and heat-treated by incubation at $100^{\circ} \mathrm{C}$ for 10 minutes, in order to destroy the residual vegetative cells. The obtained sporulation suspensions are washed with distilled water and centrifuged three times. After final washing, the spores are suspended in sterile distilled water and stored at a concentration of $10^{7}$ to $10^{8} \mathrm{sp} / \mathrm{mL}$ at $4^{\circ} \mathrm{C}$.

2.3. Antimicrobial Agents. Nisin and monolaurin were purchase from Sigma Aldrich. Standard stock solution of nisin containing $1 \times 10^{5} \mathrm{IU} / \mathrm{ml}$ was prepared by dissolving $1.25 \mathrm{~g}$ of nisin $(2.5 \%)$ in $10 \mathrm{~mL}$ sterile $0.02 \mathrm{~mol} / \mathrm{L} \mathrm{HCl}$. Monolaurin, with a purity of $99 \%$, was dissolved in $95 \%$ ethanol to a final concentration of $50 \mathrm{mg} / \mathrm{mL}$.

2.4. Experimental Design. The effect of these two antimicrobial agents on the spores has been tested. The spores, after preparation, are suspended in sterile distilled water containing different concentrations of nisin (10-50-100-500$1000-2000 \mathrm{IU} / \mathrm{ml}$ ) or in monolaurin $(50-100-250-500 \mu \mathrm{g} /$ $\mathrm{ml}$ ). Next, to assess the influence of $\mathrm{pH}$ on improving the efficacy of these antimicrobial agents on the spores of the three species studied, the spores are resuspended in sterile distilled water in the presence of nisin $(100 \mathrm{IU} / \mathrm{ml})$ and/or monolaurin $(250 \mu \mathrm{g} / \mathrm{ml})$ and at different $\mathrm{pH}$ values $(5,6,7$ and 8 ). Based on the results of preliminary tests, it can be suggested that the inactivation of Bacillus spores by the nisin-monolaurin combination varies depending on the species studied and the $\mathrm{pH}$ value tested. For this, we are interested in optimizing this process of spore inactivation using a three-factor design of experiments (nisin-monolaurin- $\mathrm{pH}$ ).

A rotatable central composite design with three independent factors was performed in order to study the inactivation of three Bacillus spores. The factors investigated were nisin $(50-150 \mathrm{IU} / \mathrm{mL})$, monolaurin $(100-300 \mu \mathrm{g} / \mathrm{mL})$, and $\mathrm{pH}(5-8)$ (Table 1).

The experiments were carried out in distilled water and UHT milk. The spores are added, after preparation, to an initial concentration $\left(\mathrm{N}_{0}\right)$ of $10^{7}$ spores $/ \mathrm{mL}$. After each treatment, the count of the spores was determined on the $\mathrm{BHI}$ agar-vit $\mathrm{B}_{12}$ medium. The experimental response is expressed as the decimal $\log$ reduction number $\left(\log \mathrm{N}_{0} / \mathrm{N}_{1}\right)$. It is estimated taking into account the influence of the experimental factors. Three experiments are carried out at the center of the experimental field, in order to estimate residual variance value. An analysis of variance and estimation of response surface by multiple linear regressions were performed using the software STATGRAPHICS Centurion XV version 15.2.06.

2.5. Response Surface Methodology (RSM). Response surface methodology (RSM) is an empirical modeling technique used to estimate the relationship between a set of 
TABLE 1: Experimental design for the central composite design.

\begin{tabular}{lccc}
\hline Trial no. & \multicolumn{3}{c}{ Factors } \\
& $x_{1}($ nisin $(\mathrm{IU} / \mathrm{ml}))$ & $x_{2}($ monolaurin $(\mu \mathrm{g} / \mathrm{ml}))$ & $x_{3}(\mathrm{pH})$ \\
\hline 1 & 100 & 250 & 7 \\
2 & 100 & 250 & 7 \\
3 & 100 & 250 & 7 \\
4 & 50 & 200 & 8 \\
5 & 150 & 300 & 6 \\
6 & 50 & 200 & 6 \\
7 & 150 & 300 & 8 \\
8 & 150 & 200 & 8 \\
9 & 50 & 300 & 8 \\
10 & 50 & 300 & 6 \\
11 & 150 & 200 & 6 \\
12 & 16 & 250 & 7 \\
13 & 184 & 250 & 7 \\
14 & 100 & 250 & 8.68 \\
15 & 100 & 250 & 5.32 \\
16 & 100 & 334 & 7 \\
17 & 100 & 166 & 7 \\
\hline
\end{tabular}

controllable experimental factors and observed results [18]. The results of fractional factorial experiment showed that nisin, monolaurin, and $\mathrm{pH}$ were the significant factors to inactivate the Bacillus spores [13]. Based on the results, response surface methodology was employed in the present work and was used to determine three log-cycles reduction of Bacillus spores in distilled water and in UHT milk under the combined treatment by nisin-monolaurin-pH. The experimental design of the investigation of experiments with three independent variables to obtain the combination of values that optimizes the response within the region of the three-dimensional observation space to allow the design of a minimal number of experimental runs [18]. The different parameters, such as nisin, monolaurin, and $\mathrm{pH}$ were chosen as key variables and designated as $X_{1}, X_{2}$, and $X_{3}$, respectively.

2.6. Enumeration of Inactivated Spores. After decimal dilution, spores suspensions that were subjected to treatment with nisin and/or monolaurin were plated on BHI agar and counted after incubation for $24 \mathrm{~h}$ at $37^{\circ} \mathrm{C}$. Log reductions were calculated as the difference between the logarithmic counts of colonies in untreated $\left(\mathrm{N}_{0}\right)$ and treated $(\mathrm{N})$ samples $\left(\log \mathrm{N}_{0}-\log \mathrm{N}\right)$.

\section{Results and Discussion}

3.1. Predictive Response Model. The combined effect of nisin, monolaurin, and $\mathrm{pH}$ on the inactivation of three Bacillus spores, isolated from milk, was studied using RSM, in distilled water and skim milk. The response $(\mathrm{Y})$ measured in terms of $\log$ cycle reduction $\left(\log \mathrm{N}_{0} / \mathrm{N}\right)$ was represented by the following second-order polynomial equation, containing 10 estimated coefficients, where $x_{1}$ is nisin concentration, $x_{2}$ is monolaurin concentration, and $x_{3}$ is $\mathrm{pH}$ (Table 2).

The analysis of variance (ANOVA), realized by statgraphics, showed that the $R^{2}$ values ranged between 0.95 and
0.99 indicating a high degree of correlation between the observed and predicted values. The $P$ values are used as a tool to check the significance of each coefficient, which in turn may indicate the pattern of interactions between variables. Table 3 demonstrated that the linear coefficients $\left(x_{1}\right.$, $x_{2}$, and $\left.x_{3}\right)$, the quadratic term coefficients $\left(x_{1}{ }^{2}, x_{2}{ }^{2}\right.$, and $\left.x_{3}^{2}\right)$, and the cross coefficients $\left(\mathrm{x}_{1} x_{2}\right.$ and $\left.\mathrm{x}_{1} x_{3}\right)$ were significant with small $P$ values $(P<0.05)$, while the cross coefficient $\left(\mathrm{x}_{2} x_{3}\right)$ was not significant $(P<0.05)$.

3.2. Localization of Optimum Conditions. The maximum inactivation of three Bacillus spores by combined effect of nisin, monolaurin, and $\mathrm{pH}$ was determined using the response surfaces and their corresponding contours plots obtained by solving the regression equations (Figures 1-3). These graphical representations permit the visualization of the relationship between the response and experimental levels of each variable. In each figure, one factor is maintained constant at the center of the experimental value determined by used software.

Figure 1 summarizes the effect of nisin and monlaurin concentrations by keeping $\mathrm{pH}$ at constant value (7). The reduction of Bacillus spores varied among tested species, nisin, and monolaurin concentrations and inoculation medium. In distilled water (Figure 1(a)), a reduction of 1.85 $\log , 2 \log$, and $3.2 \log$ was observed for, respectively, B. sporothermodurans, T. aidingensis, and Paenibacillus spores at a concentration of nisin above $150 \mathrm{IU} / \mathrm{ml}$ and of monolaurin above $150 \mu \mathrm{g} / \mathrm{ml}$, whereas in UHT milk (Figure 1(b)) and in almost the same conditions (Nisin $>80 \mathrm{IU} / \mathrm{ml}$ and monolaurin $>200 \mu \mathrm{g} / \mathrm{ml}$ ), there is a decreasing in the level of spore reduction with $1 \log$ for T. aidingensis (from 2 to $1 \log$ ), $1.2 \log$ for Paenibacillus (from 3.2 to $2 \mathrm{log}$ ), while for B. sporothermodurans, the reduction rate is almost the same in distilled water $(1.85 \mathrm{log})$ and in the milk $(1.5 \mathrm{log})$.

The combined effect of nisin (16-184 UI/ml) and $\mathrm{pH}$ $(5.32-8.68)$, in presence of monolaurin at $250 \mu \mathrm{g} / \mathrm{ml}$, on the inactivation of three Bacillus species demonstrated that the reduction rate of $B$. sporothermodurans and Paenibacillus spores is the same in both distilled water and milk $(2 \log )$ (Figure 2), but the reduction of T. aidingensis spores corresponds to $2 \log$ in distilled water and only 1 $\log$ in milk. These results highlighted the presence of an important difference between conditions of spore reduction of the evaluated species. For B. sporothermodurans spores, the maximum reduction was obtained at acid $\mathrm{pH}(5-6)$ in presence of $90 \mathrm{IU} / \mathrm{ml}$ of nisin in both milk and distilled water, while the range of $\mathrm{pH}$ for which a maximum reduction of Paenibacillus sp. spores was observed at 5-9 in both media, in presence of $190 \mathrm{IU} / \mathrm{ml}$ of nisin. For T. aidingensis spores, the inactivation conditions depend on inoculation medium. So, in distilled water, the optimum of spore reduction was achieved in basic $\mathrm{pH}$ at a concentration above $150 \mathrm{IU} / \mathrm{ml}$ of nisin, but in milk, this reduction was observed in acid $\mathrm{pH}$ at a range of nisin concentrations between 50 and $200 \mathrm{IU} / \mathrm{ml}$. 


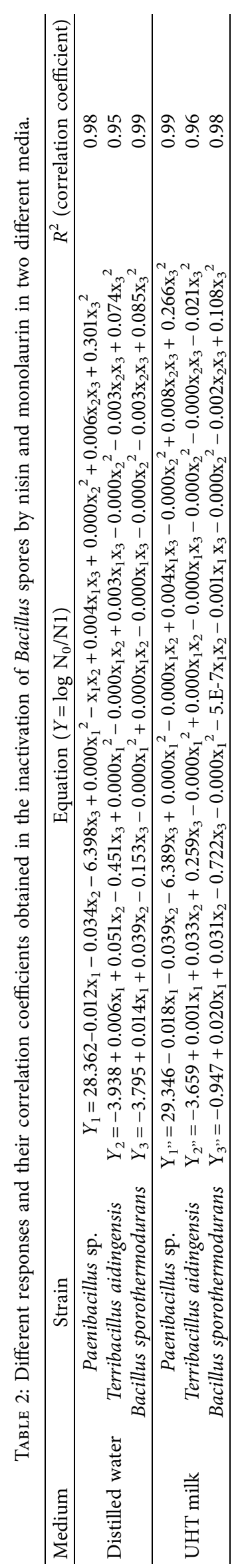


TABLE 3: Statistical significance test of the coefficients of different equations obtained in the inactivation of Bacillus spores by nisin, monolaurin, and $\mathrm{pH}$.

\begin{tabular}{|c|c|c|c|c|c|c|}
\hline \multirow{3}{*}{ Coefficient } & \multicolumn{6}{|c|}{ Probability $(P)$} \\
\hline & \multicolumn{3}{|c|}{ Distilled water } & \multicolumn{3}{|c|}{ UHT milk } \\
\hline & $\begin{array}{l}\text { Paenibacillus } \\
\text { sp. }\end{array}$ & $\begin{array}{c}\text { Terribacillus } \\
\text { aidingensis }\end{array}$ & $\begin{array}{c}\text { Bacillus } \\
\text { sporothermodurans }\end{array}$ & $\begin{array}{c}\text { Paenibacillus } \\
\text { sp. }\end{array}$ & $\begin{array}{l}\text { Terribacillus } \\
\text { aidingensis }\end{array}$ & $\begin{array}{c}\text { Bacillus } \\
\text { sporothermodurans }\end{array}$ \\
\hline $\mathbf{X}_{1}$ (Nisin) & 0.0077 & 0.0039 & 0.0000 & 0.0058 & 0.0101 & 0.0000 \\
\hline $\begin{array}{l}\mathbf{x}_{2} \\
\text { (Monolaurin) }\end{array}$ & 0.0202 & 0.0099 & 0.0055 & 0.0014 & 0.0159 & 0.1992 \\
\hline $\mathbf{x}_{3}(\mathrm{pH})$ & 0.0452 & 0.6171 & 0.0120 & 0.0114 & 0.0107 & 0.6742 \\
\hline$x_{1}{ }^{2(p i)}$ & 0.0029 & 0.8242 & 0.0022 & 0.0028 & 0.3024 & 0.0430 \\
\hline$x_{2}{ }^{2}$ & 0.6754 & 0.1412 & 0.0008 & 0.3472 & 0.0023 & 0.0173 \\
\hline $\mathrm{x}_{3}{ }^{2}$ & 0.0006 & 0.2600 & 0.0004 & 0.0004 & 0.5214 & 0.0029 \\
\hline $\mathbf{x}_{1} \mathbf{x}_{2}$ & 0.0010 & 0.0147 & 0.6976 & 0.0018 & 0.3675 & 0.9599 \\
\hline $\mathrm{x}_{2} \mathrm{x}_{3}$ & 0.0009 & 0.0502 & 0.0000 & 0.0001 & 0.7226 & 0.0031 \\
\hline $\mathrm{x}_{1} \mathrm{x}_{3}$ & 0.0060 & 0.0655 & 0.0345 & 0.0024 & 0.9741 & 0.0208 \\
\hline
\end{tabular}

The effect of monolaurin and $\mathrm{pH}$, at a fixed concentration of nisin $(100 \mathrm{IU} / \mathrm{ml})$, on the inactivation of the evaluated Bacillus spores is given in Figure 3. From the analysis of obtained data, we can notice that the rate of spore reduction is the same, which is calculated previously. Indeed, for B. sporothermodurans spores, the optimum reduction was obtained at acid $\mathrm{pH}$ with a concentration of monolaurin between 250 and $300 \mu \mathrm{g} / \mathrm{ml}$ in both media. For Paenibacillus spores, in the range of $\mathrm{pH}$ of 5 to 9 and monolaurin concentrations of 150 to $300 \mu \mathrm{g} / \mathrm{ml}$, the reduction rate corresponds to $2 \mathrm{log}$, while for T. aidingensis, the optimum of spore reduction $(2 \log$ ) was observed at basic $\mathrm{pH}$ and a concentration of monolaurin between 150 and $180 \mu \mathrm{g} / \mathrm{ml}$ in distilled water, and $1 \log$ spore reduction was reached in milk at acid $\mathrm{pH}$ with concentrations of monolaurin ranging from 190 to $290 \mu \mathrm{g} / \mathrm{ml}$.

By analyzing the nisin-monolaurin-pH plots, it can be noticed that the effect of nisin and monolaurin against Bacillus spores depends on the concentrations of these two antimicrobials agents and $\mathrm{pH}$ values. In fact, the spore inactivation found in UHT milk was not significantly different from that obtained in distilled water in the case where nisin and monolaurin concentrations maintained at $100 \mathrm{IU} / \mathrm{ml}$ and $250 \mu \mathrm{g} / \mathrm{ml}$, respectively. This remark is different from that reported in previous studies, which demonstrated that food components may act on treatment efficiency by either decreasing or increasing the inactivation bacteria. Our results are in agreement with the findings of Aouadhi et al. [11] who reported that the inactivation of B. sporothermodurans spores by nisin, moderate heating, and high pressure is the same in both milk and distilled water, whereas when the $\mathrm{pH}$ was maintained at its optimum value (7), the level of spore reduction was higher in distilled water than in milk. This result confirms that when spores were treated in food matrices, a slight protective effect was noted for spores treated in milk.

In addition, the obtained results demonstrated that the nisin-monolaurin combination was more effective in reduction of Bacillus spores than either agent used alone. Since the preliminary tests of the sensibility of Bacillus spores showed that the maximum inhibition was $1.6 \log$ for
B. sporothermodurans spores by nisin $(100 \mathrm{IU} / \mathrm{ml})$ and 1.7 $\log$ with $2000 \mathrm{IU} / \mathrm{ml}$ of nisin, while in the presence of monolaurin, the reduction rate was $1.4 \log$ for B. sporothermodurans and $1.7 \log$ for Paenibacillus spores obtained in the presence of $250 \mu \mathrm{g} / \mathrm{ml}$ and $500 \mu \mathrm{g} / \mathrm{ml}$, respectively (data not shown), whereas the combining effect of nisin-monolaurin increased the level of spore reduction for B. sporothermodurans (3 log), Paenibacillus, and T. aidingensis $(2 \mathrm{log})$. So, this result showed that there is an inhibitory synergistic effect of nisin-monolaurin combination against Bacillus species. Also, several researchers reported that most of antimicrobial compounds studied showed inhibitory effects (prevention of microbial outgrowth and recovery during storage), some including monolaurin and nisin which have been capable of enhancing process lethality against bacterial spores [19].

The different effect of the tested inhibitors on Bacillus spore was due to their different mechanisms of action, though the cytoplasmic membrane is their primary site of action, which can explain their inhibitory synergistic effect. Nisin binds into the membrane, is inserted into it, and forms pores leading to proton motive force dissipation and to efflux of many vital intracellular compounds [20]. The effect of nisin against bacterial spores is likely to be sporostatic rather than sporicidal [6], and it has been suggested to be the result of its binding to sulfhydryl groups on protein residues [21]. Nisin prevents outgrowth of spores of C. botulinum and $B$. cereus [22], as spore outgrowth rather than spore germination is inhibited by the presence of nisin [23], whereas Delves-Broughton [24] suggested that the nisin action against spores is far less understood than for vegetative cells. It is predominantly sporostatic rather than sporicidal.

While according to Ababouch et al. $[25,26]$, monolaurin was able to inhibit the process of spore germination. Bacterial endospore germination has been defined as the degradation process by which the dormant state is irreversibly terminated. Germination is followed by an outgrowth, which is the process of synthesis of new bacterial macromolecules and conversion of germinated spores into a newly emerged vegetative cell. The mechanism of outgrowth inhibition by monoacylglycerols MAG was suggested as an inhibition of 
Paenibacillus sp
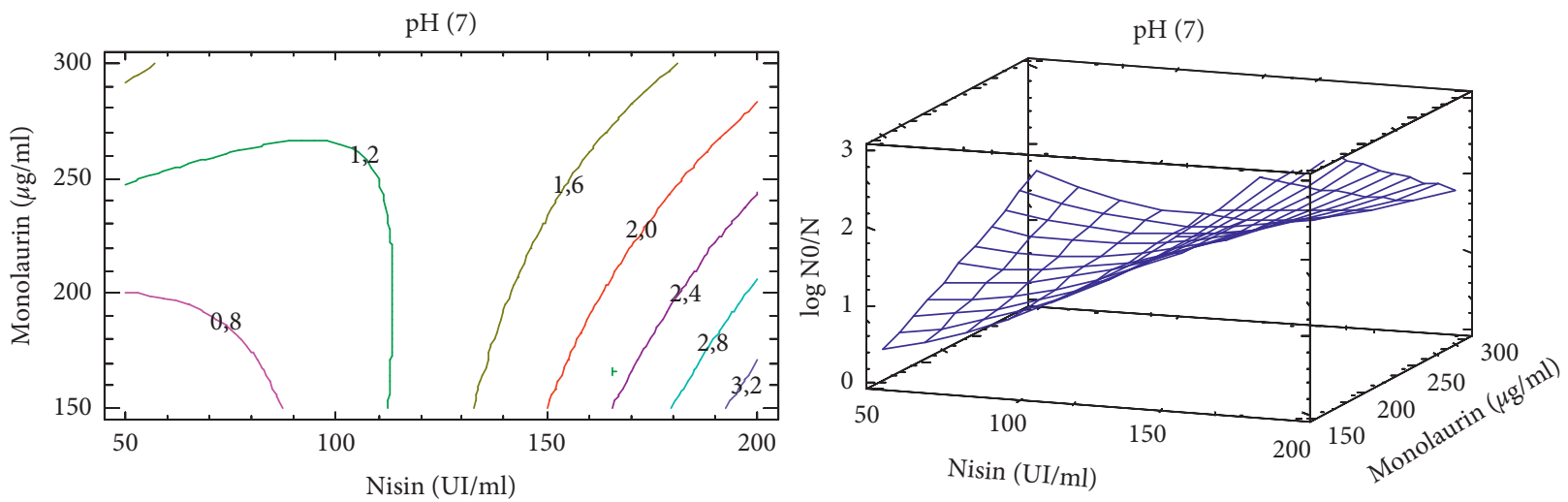

Bacillus sporothermodurans
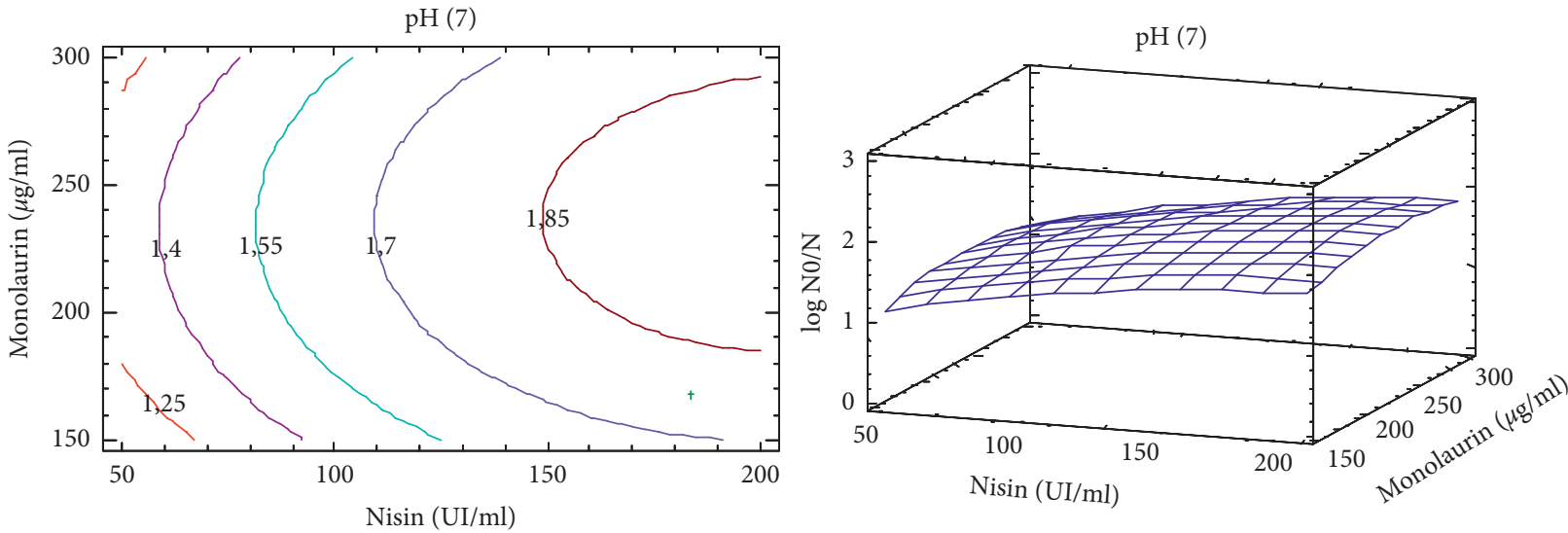

Terribacillus aidingensis
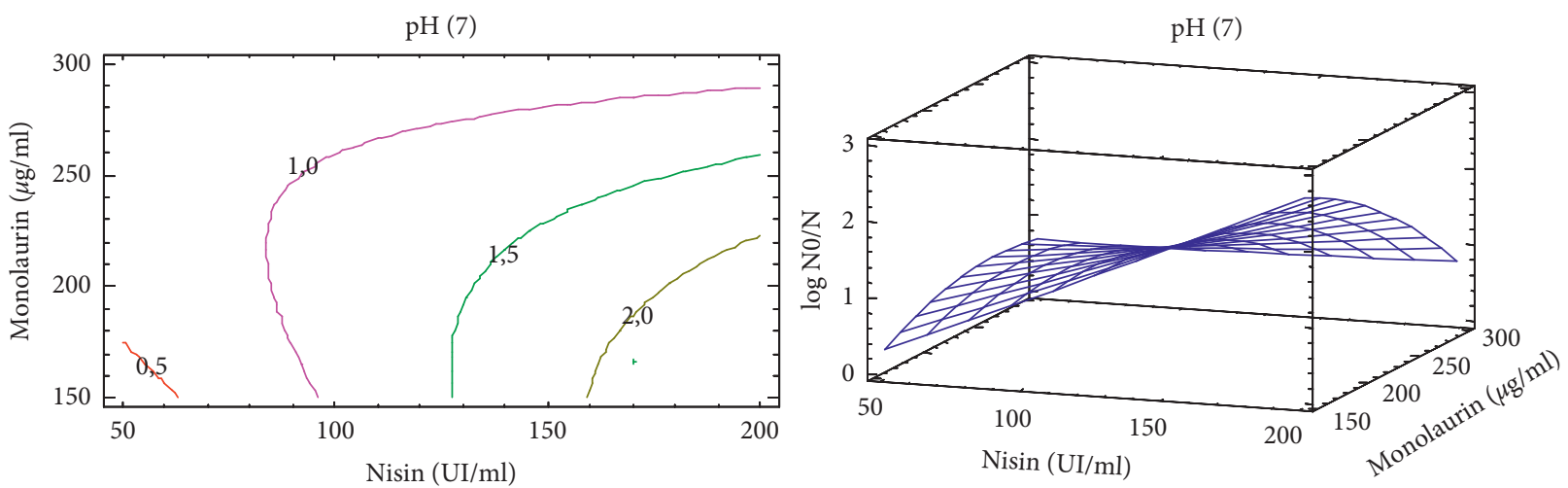

(a)

Figure 1: Continued. 
Paenibacillus sp
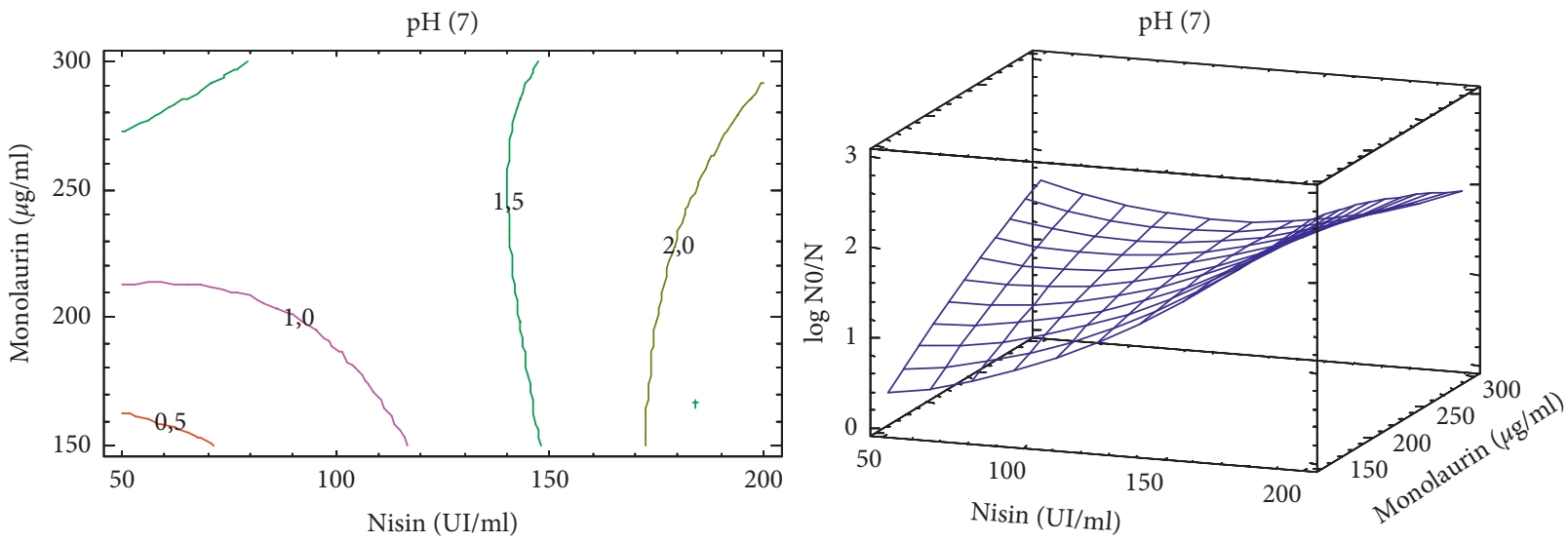

Bacillus sporothermodurans
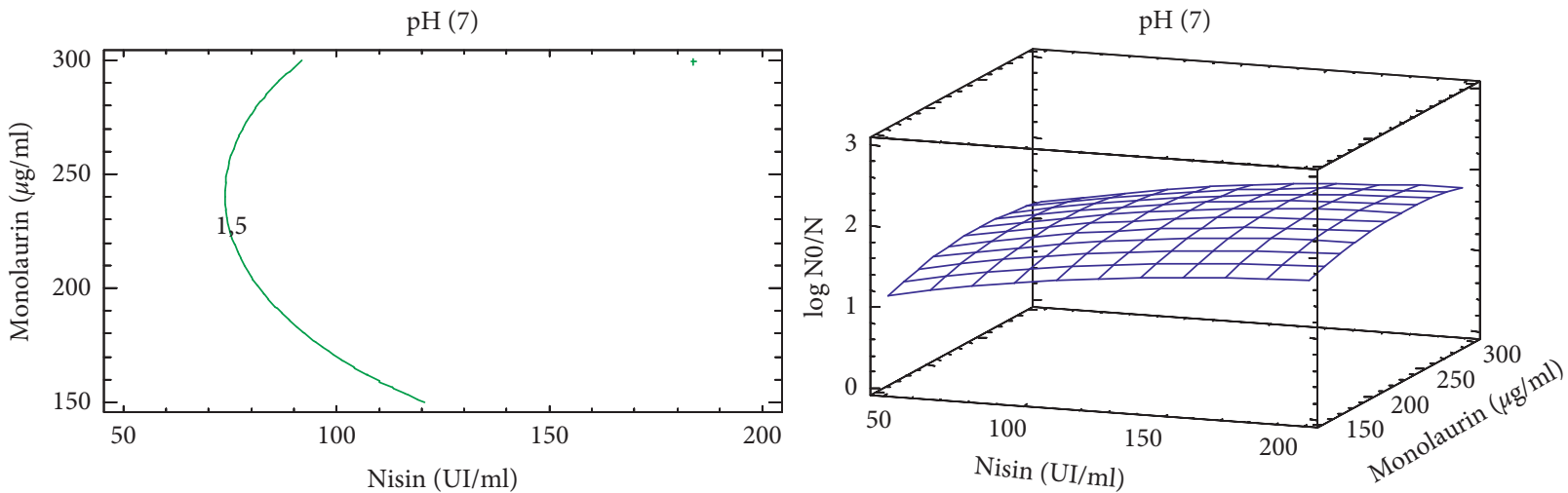

Terribacillus aidingensis
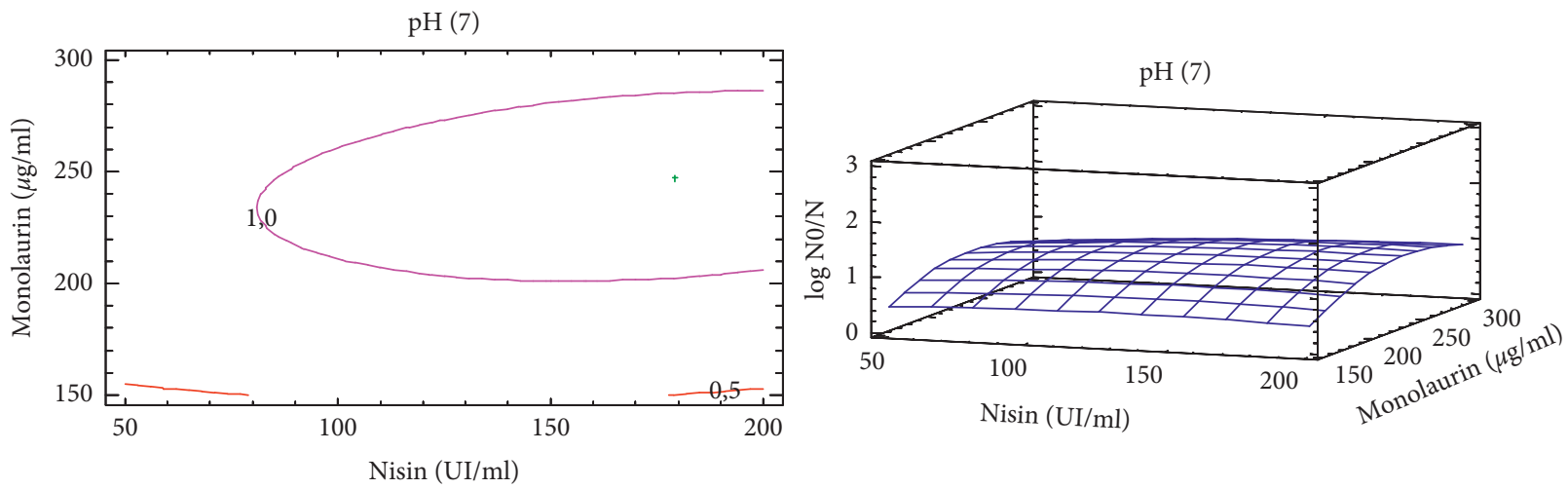

(b)

FIGURE 1: Response surface and contour plots showing the effects of nisin and monolaurin on the spores' inactivation in distilled water (a) and milk (b). The data on the contour maps are $\log \mathrm{N}_{0} / \mathrm{N} . \mathrm{N}_{0}$ represents the plate count of the untreated spore suspension (10 ${ }^{7}$ spores $/ \mathrm{ml}$ ), and $\mathrm{N}$ represents the plate count after treatment with antimicrobial agents. 
Paenibacillus sp
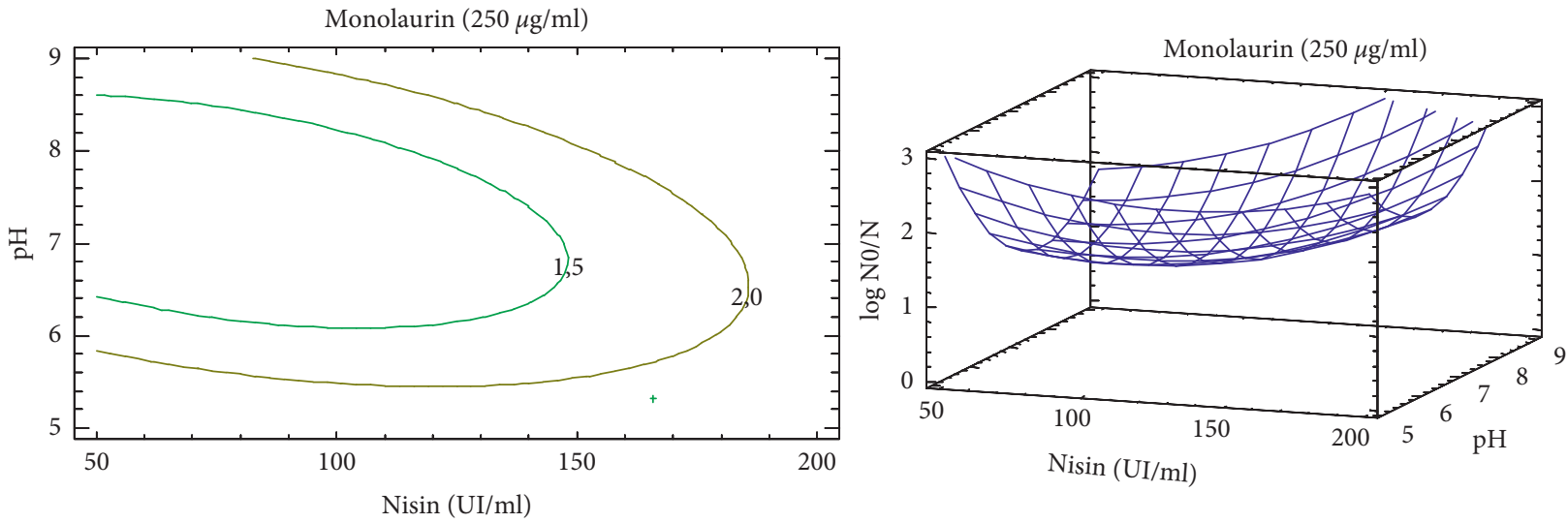

Bacillus sporothermodurans
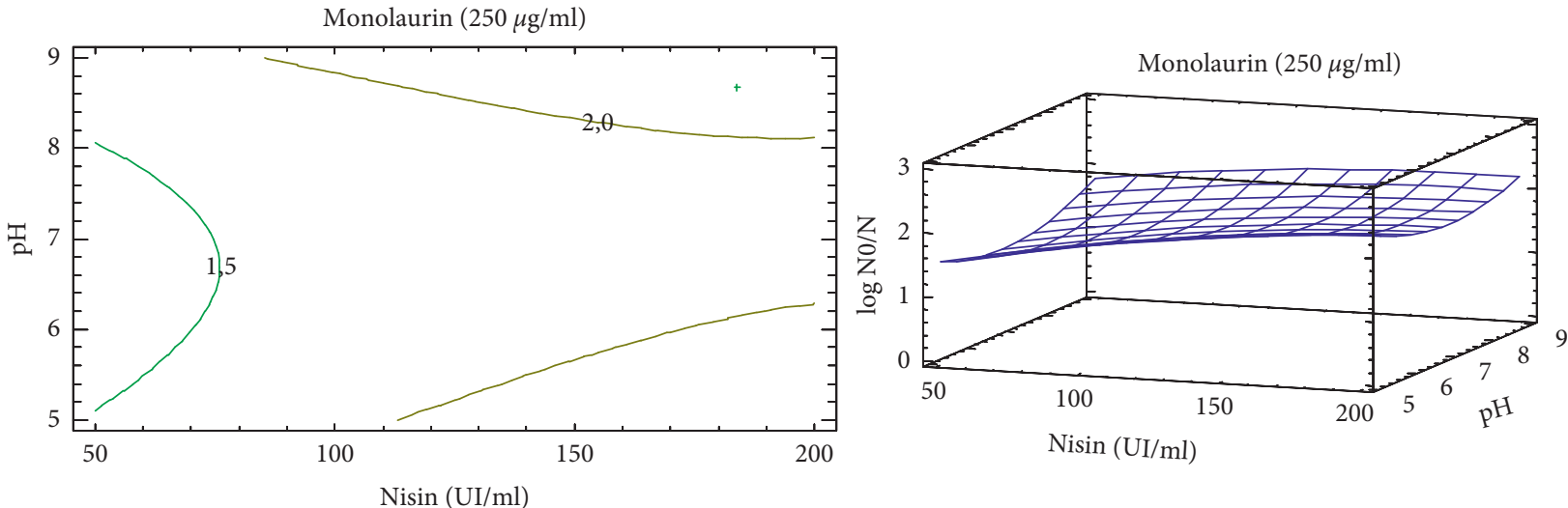

Terribacillus aidingensis
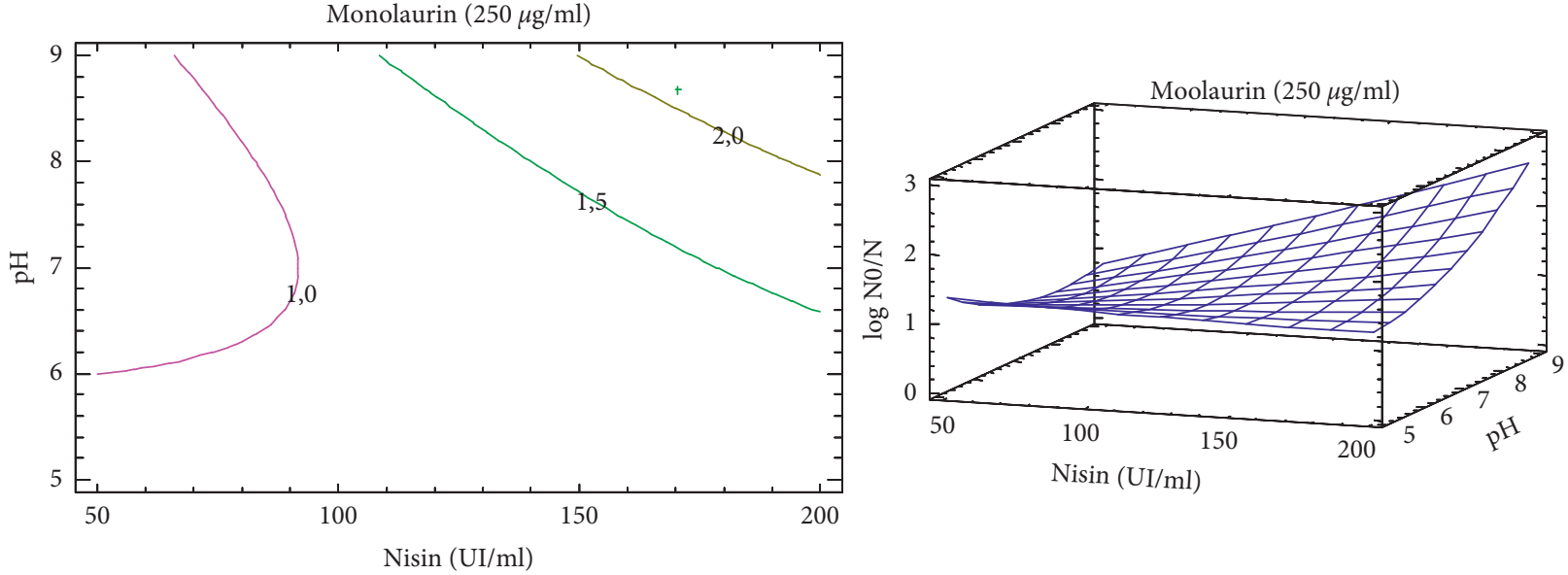

(a)

Figure 2: Continued. 
Paenibacillus sp
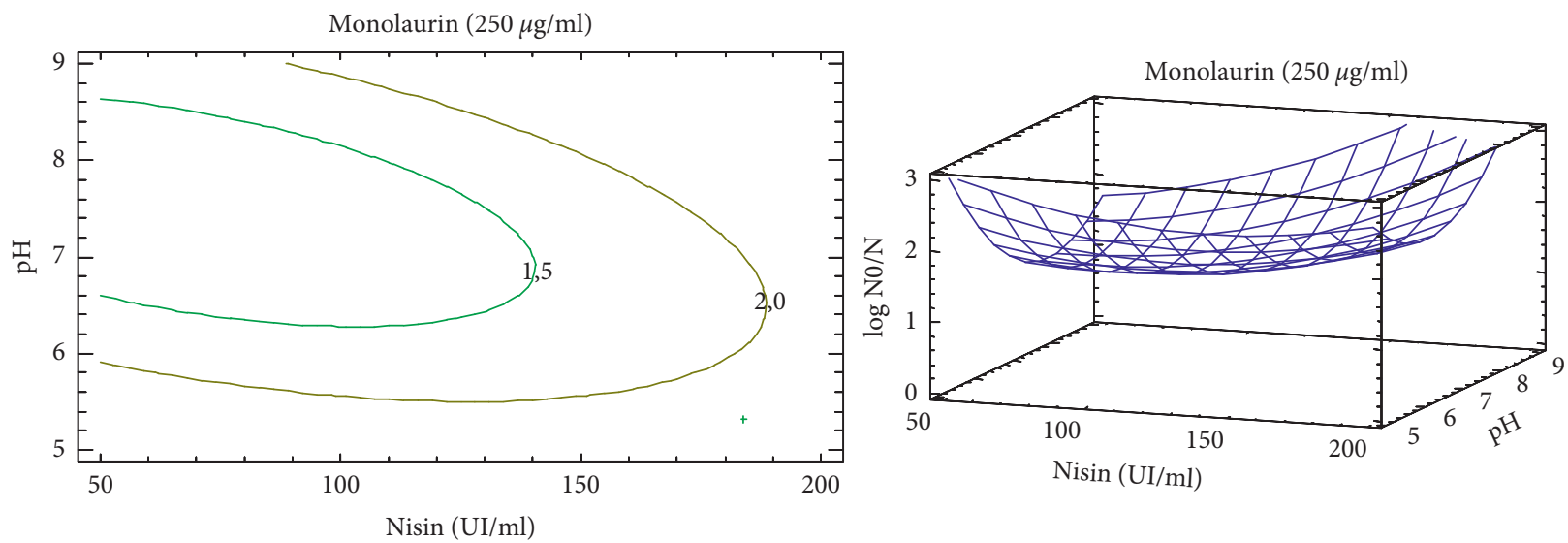

Bacillus sporothermodurans
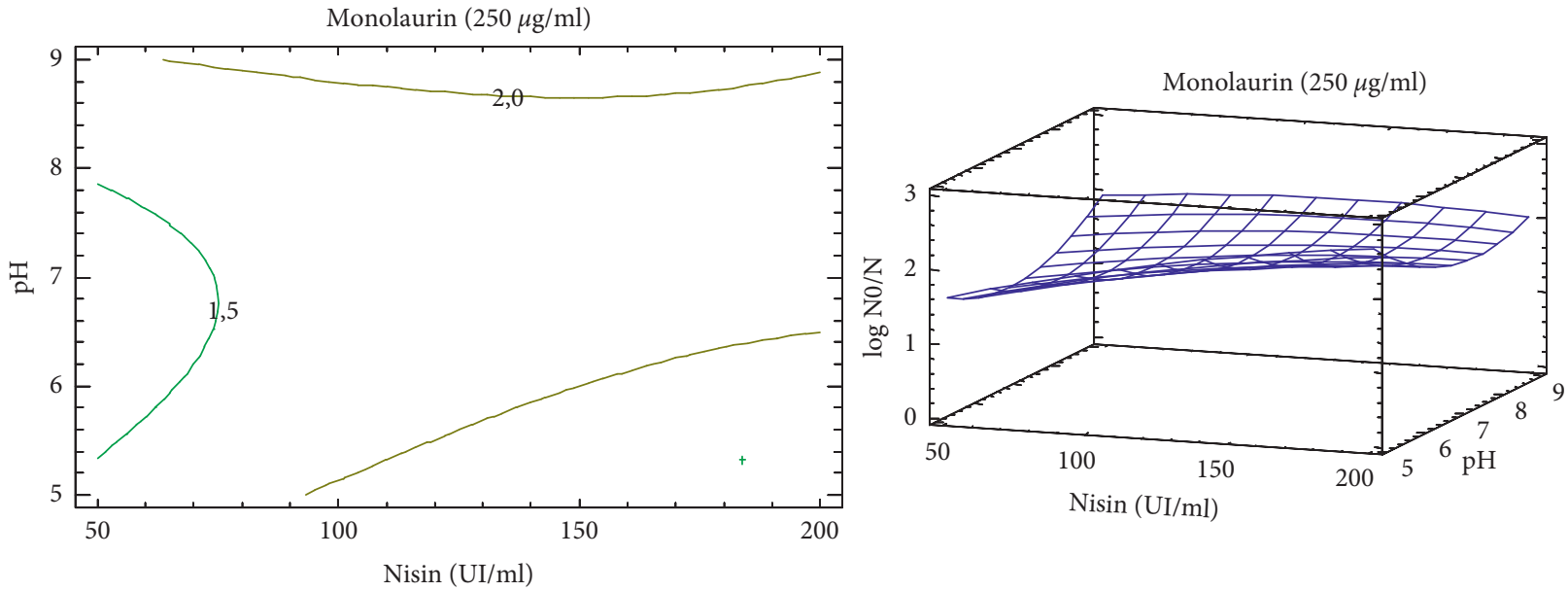

Terribacillus aidingensis
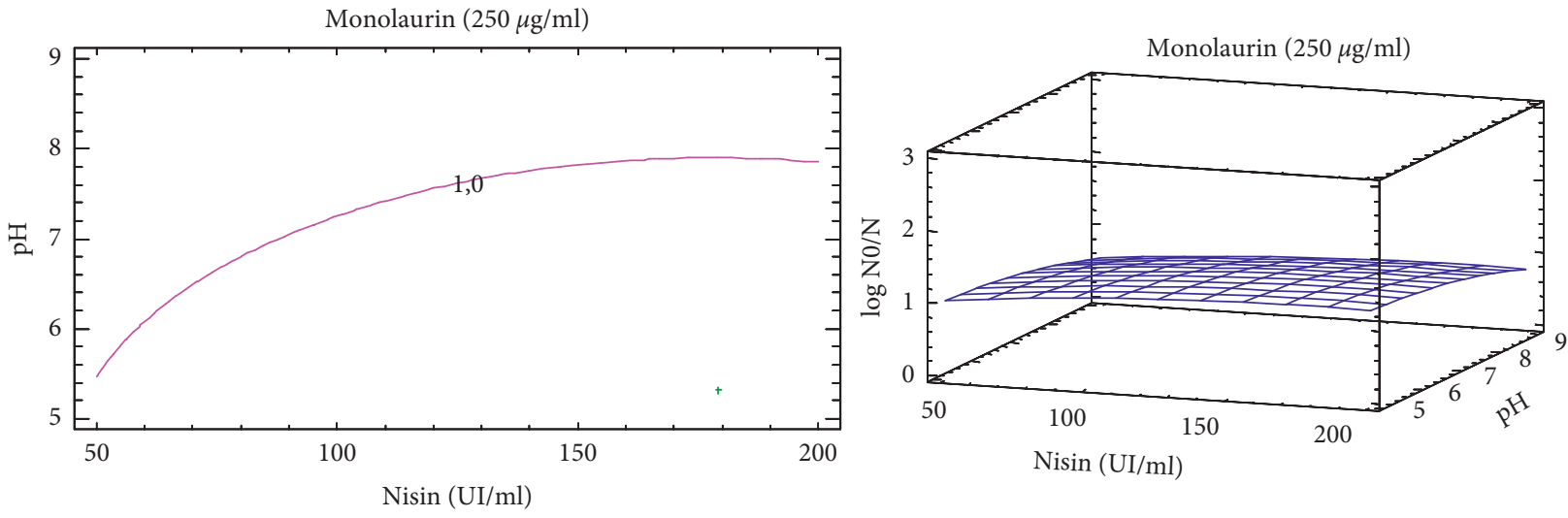

(b)

FIGURE 2: Response surface and contour plots showing the effects of nisin and $\mathrm{pH}$ on the spores' inactivation in (a) distilled water and (b) milk. ${ }^{*}$ The data on the contour maps are $\log \mathrm{N}_{0} / \mathrm{N}$. $\mathrm{N}_{0}$ represents the plate count of the untreated spore suspension $\left(10^{7}\right.$ spores $\left./ \mathrm{ml}\right)$, and $\mathrm{N}$ represents the plate count after treatment with antimicrobial agents.

oxygen consumption, which indicates that the inner membrane and its enzymes responsible for oxygen transport are the possible sites of action. The usefulness of monolaurin in the heat inactivation of spores was substantiated by Kimsey et al. [27], who showed enhanced thermal inactivation of Geobacillus stearothermophilus in the presence of monolaurin. It was included that monolaurin could be used as food additive to reduce the heat treatment required to achieve commercial sterility of foods. The lipophilic nature of monolaurin, its emulsification properties, 
Paenibacillus sp
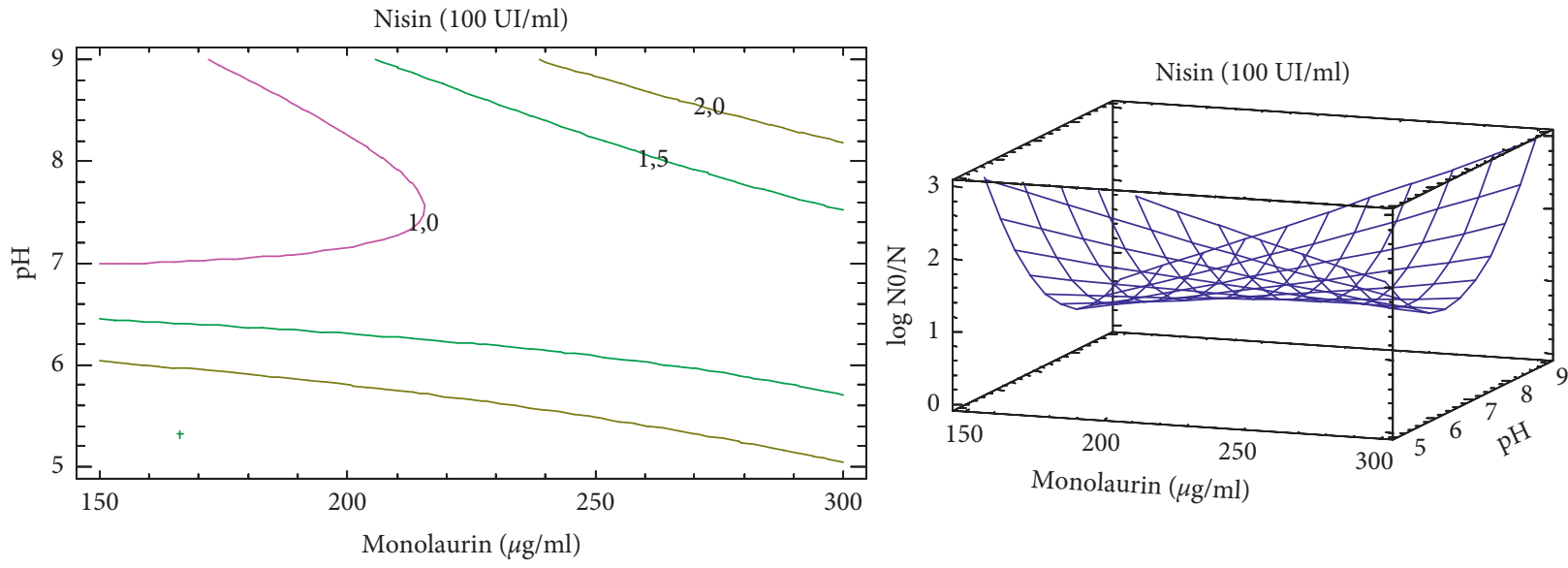

Bacillus sporothermodurans
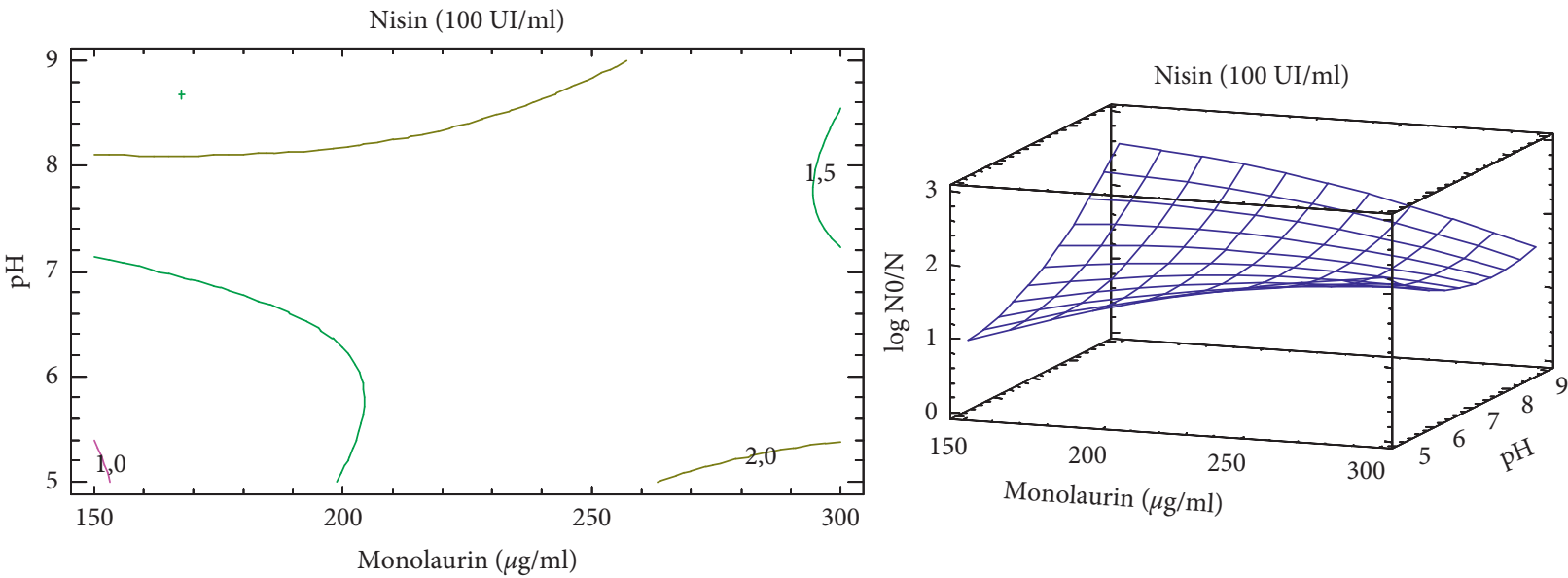

Terribacillus aidingensis
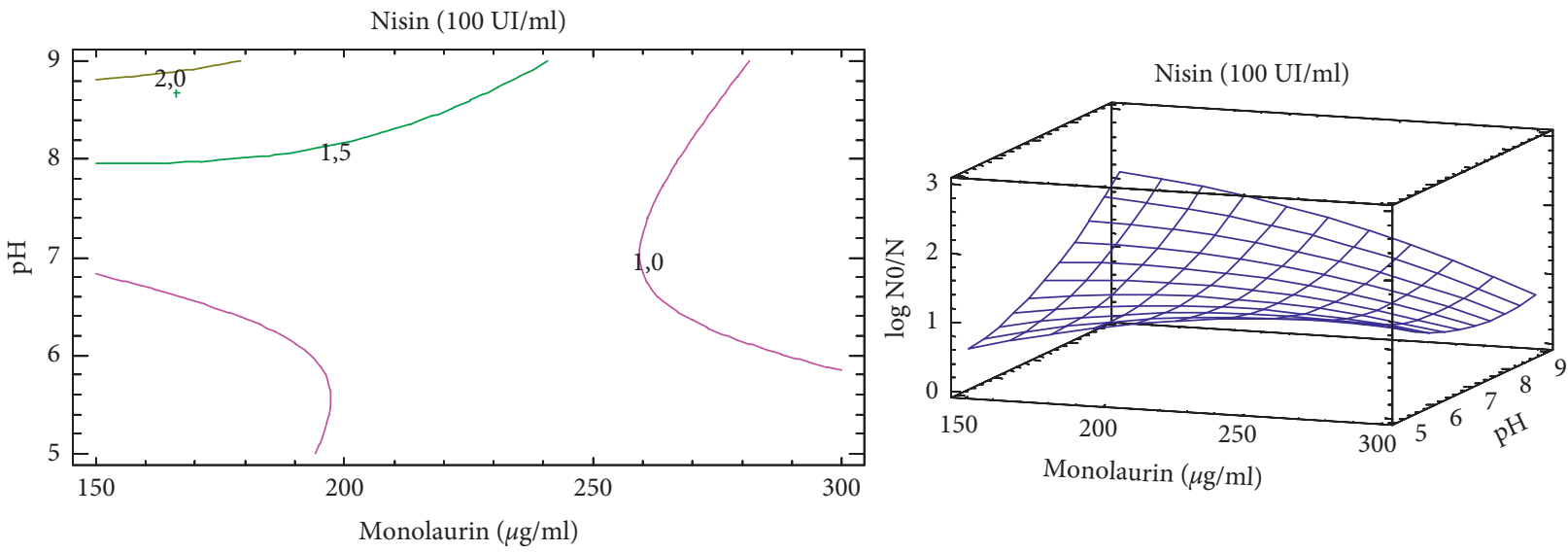

(a)

Figure 3: Continued. 
Paenibacillus sp
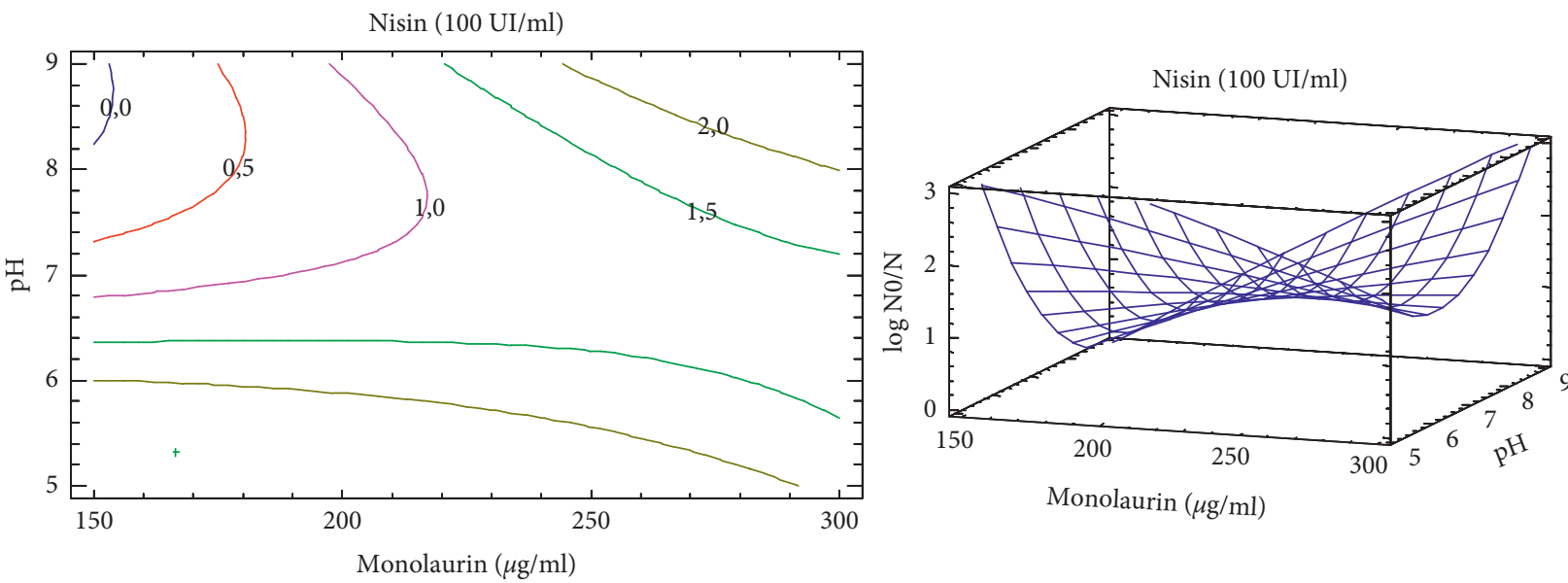

Bacillus sporothermodurans
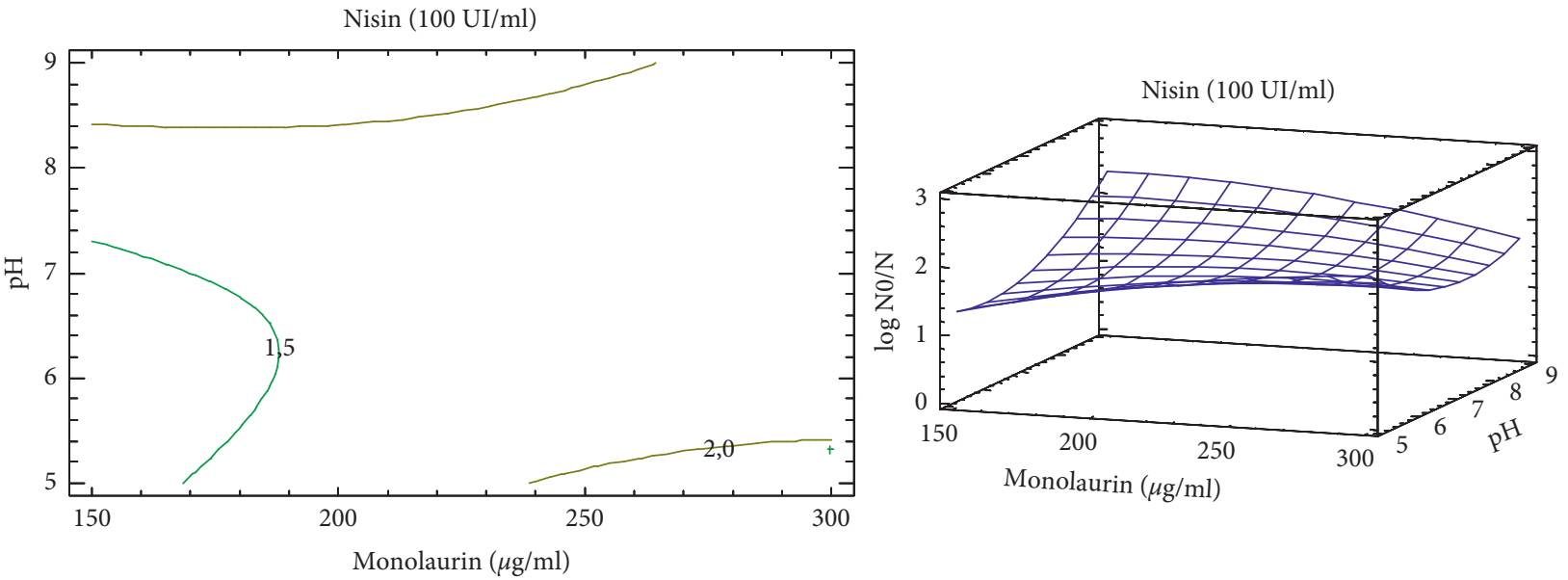

Terribacillus aidingensis
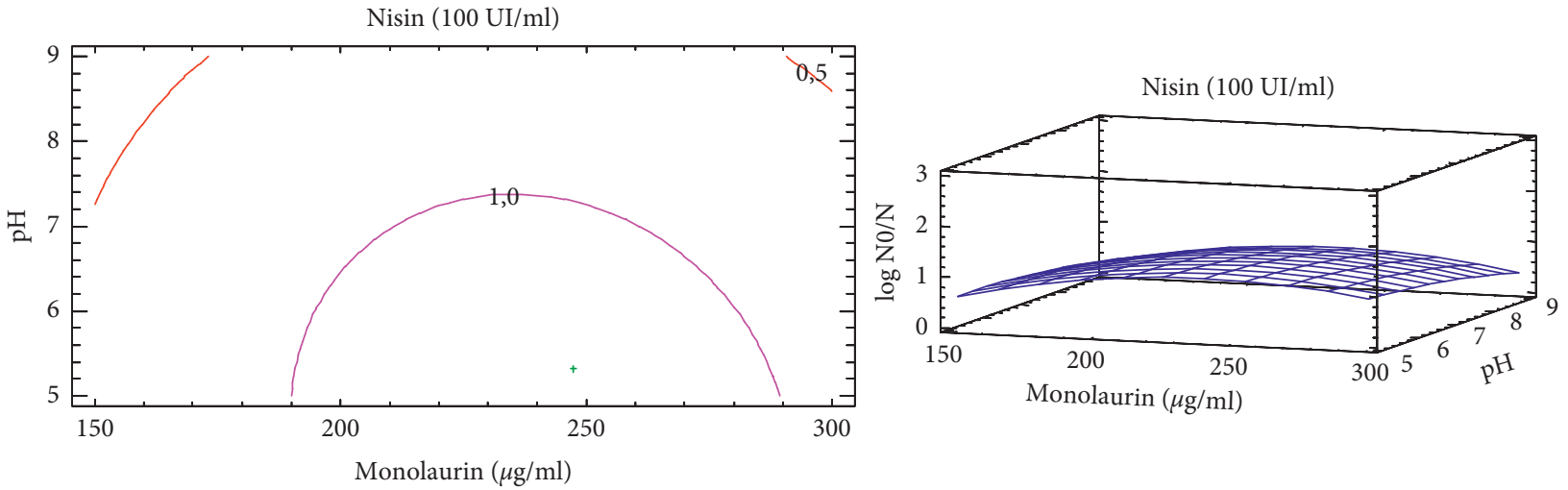

(b)

FigURE 3: Response surface and contour plots showing the effects of monolaurin and pH on the spores' inactivation in distilled (a) water and (b) milk ${ }^{*}$ The data on the contour maps are $\log \mathrm{N}_{0} / \mathrm{N}$. $\mathrm{N}_{0}$ represents the plate count of the untreated spore suspension $\left(10^{7} \mathrm{spores} / \mathrm{ml}\right)$, and $\mathrm{N}$ represents the plate count after treatment with antimicrobial agents.

evidence of fatty acid inhibition of cells through interaction with the cell membranes, and the reports of spore membranes as a site of thermal damage in $C$. perfringens, C. botulinum, and B. stearothermophilus spores [28] suggested that monolaurin could be interacting with spore membranes and sensitizing them to heat. The antimicrobial activity of monolaurin is produced through its ability to destabilize the functions of the membrane and is enhanced with lactate, sorbate, ascorbate, and nisin. Monolaurin was partially sporicidal [29]. 
Many researchers suggested that simultaneous addition of nisin and monolaurin was reported to inhibit the growth of $B$. licheniformis [13] and in another study showed bactericidal activity against several Bacillus species, preventing both sporulation and regrowth in skimmed milk [10].

Moreover, $\mathrm{pH}$ influences the activity of these two antimicrobial agents. So, when combining nisin and monolaurin, their antimicrobial activity increased with increasing $\mathrm{pH}$ values (7.0) [13]. This same study showed that monolaurin and nisin acted synergistically on vegetative cells and outgrown spores, showing total inhibition at $\mathrm{pH} 6$ of $B$. licheniformis spores in milk, although monolaurin enhanced thermal inactivation of B. cereus spores in $\mathrm{pH} 7.2$ phosphate buffer, inhibited outgrowth of Bacillus spp., Geobacillus stearothermophilus, Alicyclobacillus spp., and $C$. sporogenes spores in a model agar system, enhanced high pressure inactivation of B.subtilis spores in milk [7, 19, 30], and inhibited spore growth in milk [31], while other researchers demonstrated that the influence of monolaurin on B. stearothermophilus spores did not appear to be $\mathrm{pH}$ dependant over the range of $\mathrm{pH} 6$ to 8 [27].

So, inactivation of Bacillus spores by combined treatment nisin-monolaurin depends on a range of factors, related to the species, the physical parameters of treatment (such as $\mathrm{pH}$ ), and the medium in which bacterial spores are suspended. Furthermore, while combining nisin and monolaurin produces additive effects, more studies are necessary to determine if these agents might also work well in the presence of other antimicrobial agents or physical parameters to make them more effective to inhibit, completely, bacterial spores.

\section{Conclusion}

The obtained results illustrate the presence of a synergistic effect between nisin and monolaurin against three Bacillus spores. The synergistic effect related to this study could offer an original alternative for controlling these bacterial spores and could increase the scope for nisin and monolaurin usage within the food industry. The combination of these two antimicrobials would improve the shelf life of many food products. This result appears to be promising for the dairy industry and offer an alternative to high heat processing is desired. Nevertheless, further investigations and more refining of parameters of the combined treatment by nisinmonolaurin are necessary to attempt complete spore inhibition in dairy products.

\section{Abbreviations}

\section{Data Availability}

No data were used to support this study.

\section{Conflicts of Interest}

The authors declare no conflicts of interest.

\section{Acknowledgments}

The authors acknowledge the financial support provided by the Tunisian Ministry of Higher Education and Scientific Research.

\section{References}

[1] P. Scheldeman, K. Goossens, M. Rodriguez-Diaz et al., "Paenibacillus lactis sp. nov., isolated from raw and heattreated milk," International Journal of Systematic and Evolutionary Microbiology, vol. 54, no. 3, pp. 885-891, 2004.

[2] M. Z. Durak, H. I. Fromm, J. R. Huck, R. N. Zadoks, and K. J. Boor, "Development of molecular typing methods for Bacillus spp. and Paenibacillus spp. isolated from fluid milk products," Journal of Food Science, vol. 71, no. 2, pp. M50-M56, 2006.

[3] P. Scheldeman, L. Herman, S. Foster, and M. Heyndrickx, "Bacillus sporothermodurans and other highly heat-resistant spore formers in milk," Journal of Applied Microbiology, vol. 101, no. 3, pp. 542-555, 2006.

[4] B. Pettersson, F. Lembke, P. Hammer, E. Stackebrandt, and F. G. Priest, "Bacillus sporothermodurans, a new species producing highly heat-resistant endospores," International Journal of Systematic Bacteriology, vol. 46, no. 3, pp. 759-764, 1996.

[5] E. P. Black, M. Linton, R. D. McCall et al., "The combined effects of high pressure and nisin on germination and inactivation ofBacillusspores in milk," Journal of Applied Microbiology, vol. 105, no. 1, pp. 78-87, 2008.

[6] J. Delves-Broughton, P. Blackburn, R. J. Evans, and J. Hugenholtz, "Applications of the bacteriocin, nisin," Antonie van Leeuwenhoek, vol. 69, no. 2, pp. 193-202, 1996.

[7] A. Chaibi, L. H. Ababouch, and F. F. Busta, "Inhibition by monoglycerides of L-alanine-triggered Bacillus cereus and Clostridium botulinum spore germination and outgrowth," Journal of Food Protection, vol. 59, no. 8, pp. 832-837, 1996.

[8] L.-L. Wang and E. A. Johnson, "Control of Listeria monocytogenes by monoglycerides in foods," Journal of Food Protection, vol. 60, no. 2, pp. 131-138, 1997.

[9] J. L. Arqués, E. Rodríguez, M. Nuñez, and M. Medina, "Antimicrobial activity of nisin, reuterin, and the lactoperoxidase system on Listeria monocytogenes and Staphylococcus aureus in cuajada, a semisolid dairy product manufactured in Spain," Journal of Dairy Science, vol. 91, no. 1, pp. 70-75, 2008.

[10] M. Mansour and J.-B. Millière, "An inhibitory synergistic effect of a nisin-monolaurin combination on Bacillus sp. vegetative cells in milk," Food Microbiology, vol. 18, no. 1, pp. 87-94, 2001.

[11] C. Aouadhi, H. Simonin, S. Mejri, and A. Maaroufi, "The combined effect of nisin, moderate heating and high hydrostatic pressure on the inactivation of Bacillus sporothermodurans spores," Journal of Applied Microbiology, vol. 115, no. 1, pp. 147-155, 2013.

[12] H. Zhang, H. Wei, Y. Cui, G. Zhao, and F. Feng, "Antibacterial interactions of monolaurin with commonly used antimicrobials and food components," Journal of Food Science, vol. 74, no. 7, pp. M418-M421, 2009.

[13] M. Mansour, D. Amri, A. Bouttefroy, M. Linder, and J. B. Milliere, "Inhibition ofBacillus licheniformisspore growth in milk by nisin, monolaurin, and $\mathrm{pH}$ combinations," Journal of Applied Microbiology, vol. 86, no. 2, pp. 311-324, 1999. 
[14] T. J. Montville, K. Winkowski, and R. D. Ludescher, "Models and mechanisms for bacteriocin action and application," International Dairy Journal, vol. 5, no. 8, pp. 797-814, 1995.

[15] C. Aouadhi, Z. Rouissi, S. Mejri, and A. Maaroufi, "Inactivation of Bacillus sporothermodurans spores by nisin and temperature studied by design of experiments in water and milk," Food Microbiology, vol. 38, pp. 270-275, 2014.

[16] S. Kmiha, C. Aouadhi, A. Klibi et al., "Seasonal and regional occurrence of heat-resistant spore-forming bacteria in the course of ultra-high temperature milk production in Tunisia," Journal of Dairy Science, vol. 100, no. 8, pp. 6090-6099, 2017.

[17] L. M. Herman, M. J. Vaerewijck, R. J. Moermans, and G. M. Waes, "Identification and detection of Bacillus sporothermodurans spores in 1, 10, and 100 milliliters of raw milk by PCR," Applied and Environmental Microbiology, vol. 63, no. 8, pp. 3139-3143, 1997.

[18] Y.-L. Gao and H.-H. Jiang, "Optimization of process conditions to inactivate Bacillus subtilis by high hydrostatic pressure and mild heat using response surface methodology," Biochemical Engineering Journal, vol. 24, no. 1, pp. 43-48, 2005.

[19] A. Chaibi, L. H. Ababouch, M. R. Ghouila, and F. F. Busta, "Effect of monoglycerides on the thermal inactivation kinetics ofBacillus cereusF4165/75 spores," Food Microbiology, vol. 15, no. 5, pp. 527-537, 1998.

[20] T. J. Montville, H.-J. Chung, M. L. Chikindas, and Y. Chen, "Nisin A depletes intracellular ATP and acts in bactericidal manner against Mycobacterium smegmatis*," Letters in Applied Microbiology, vol. 28, no. 3, pp. 189-193, 1999.

[21] S. L. Morris, R. C. Walsh, and J. N. Hansen, "Identification and characterization of some bacterial membrane sulfhydryl groups which are targets of bacteriostatic and antibiotic action," Journal of Biological Chemistry, vol. 259, no. 21, pp. 13590-13594, 1984.

[22] H. Chen and D. G. Hoover, "Pressure inactivation kinetics of Yersinia enterocolitica ATCC 35669," International Journal of Food Microbiology, vol. 87, no. 1-2, pp. 161-171, 2003.

[23] G. W. Gould, "Effect of food preservatives on the growth of bacterial spores," Microbial Inhibitors in Food, pp. 17-24, 1964.

[24] J. Delves-Broughton, "Nisin as a food preservative," Food Australia, vol. 57, pp. 525-529, 2005.

[25] L. H. Ababouch, F. Bouquartacha, and F. F. Busta, "Inhibition of l-alanine triggered Bacillus cereus T spore germination and outgrowth by fatty acids and glyceryl monododecanoate," Food Microbiology, vol. 11, no. 5, pp. 385-396, 1994a.

[26] L. H. Ababouch, F. Bouqartacha, and F. F. Busta, "Inhibition of Bacillus cereus spores and vegetative cells by fatty acids and glyceryl monododecanoate," Food Microbiology, vol. 11, no. 4, pp. 327-336, 1994b.

[27] H. R. Kimsey, D. M. Adams, and J. J. Kabara, "Increased inactivation of bacterial spores at high temperatures in the presence of Monoglycerides2," Journal of Food Safety, vol. 3, no. 2, pp. 69-82, 1981.

[28] R. S. Flowers and D. M. Adams, "Spore membrane (s) as the site of damage within heated Clostridium perfringens spores," Journal of Bacteriology, vol. 125, no. 2, pp. 429-434, 1976.

[29] Bibek Ray Arun Bhunia 2013. Technology \& Engineering Fundamental Food Microbiology.

[30] A. E. H. Shearer, C. P. Dunne, A. Sikes, and D. G. Hoover, "Bacterial spore inhibition and inactivation in foods by pressure, chemical preservatives, and mild heat," Journal of Food Protection, vol. 63, no. 11, pp. 1503-1510, 2000.
[31] S. J. Projan, S. Brown-Skrobot, P. M. Schlievert, F. Vandenesch, and R. P. Novick, "Glycerol monolaurate inhibits the production of beta-lactamase, toxic shock toxin-1, and other staphylococcal exoproteins by interfering with signal transduction," Journal of Bacteriology, vol. 176, no. 14, pp. 4204-4209, 1994. 